\title{
DEBATINDLAEG
}

\section{Vejledning for ældre: Gerontovejledning?}

\section{Peter Plant}

Der bliver flere ældre. Det grå guld er på arbejdsmarkedet og skulle gerne blive der. De ældre er en resurse. Har de brug for vejledning - gerontovejledning?

Geront (fra græsk): 'olding'; medlem af byrådet i det gamle Sparta.

\section{Geront}

De gamle geronter i Sparta sad i byrådet netop, fordi de var ældre - og helt givet meget vise. Det grå guld i vore dages samfund lytter til festtalerne om, hvor vigtige deres resurser er på arbejdsmarkedet, men mange ældre finder det alligevel vanskeligt at genfinde eller fastholde et fodfæste på arbejdsmarkedet deltids-, heltids- eller f.eks. frivilligt arbejde. Deres visdom og erfaringer er ikke altid så påskønnet, når det kommer til stykket. $\mathrm{Og}$ rigtig svært er det at finde et job som 55- årig efter periode med arbejdsløshed. Vejlederne har en opgave her: ikke med en snæver arbejdsmarkedsrettet vejledning, men med en bred vejledningsindsats, som omfatter både arbejdsliv og de andre liv (Plant, 2010). Det er livet det gælder. Og det er på tide at vejledere åbner øjnene for disse behov. Der findes andet end ungdom: vi tilbringer det meste af vores liv som godt voksne. Der er meget at forske i på dette felt - og der er megen praksis at udvikle. Det er åbent land.
Guleroden dingler dér fremme: hæng på så længe du kan, du gamle. Udsæt pensionen. Det er der gode demografiske og samfundsøkonomiske grunde til at gøre. For der bliver flere ældre og færre unge. Og de ældre lever længere. Pensionsalderen op mod de 67 år er fastsat i en tid, hvor folk ikke blev så gamle som nu. Hvis livslængden stiger til 90 år i gennemsnit, så skal pensionsalderen måske være 80 år? Så bliver det rigtigt svært at aldersdiskriminere fra 45-års alderen på arbejdsmarkedet.

\section{Senior}

Argumenterne for at de ældre skal blive på arbejdsmarkedet bliver jævnligt hamret ud. Sammenlignet med yngre medarbejdere er seniorer, dvs. folk over ca. 55 år:

- Mere stabile, både hvad angår den daglige stabilitet og i længden

- Mere flexible i forhold til arbejdstider 
- Mere ansvarlige

- Mere erfarne og rutinerede

- Mere vellidt af kunder

Og alligevel er det svært for nogle grupper af ældre på arbejdsmarkedet at finde job. Hvorfor? Bl.a. fordi en række barrierer stiller sig hindrende i vejen:

- Nogle virksomheder har et langt ansættelsesperspektiv og forventer at medarbejdere bliver mange år på virksomheden: det diskriminerer de ældre, fordi de forventes at have et forholdsvis kortere tidsperspektiv på jobbet, blot på grund af deres alder

- Andre virksomheder har et kort ansættelsesperspektiv og forventer, at medarbejdere hurtigt flytter sig til nye jobs. Det gør de ældre ikke: det diskriminerer også de ældre

- Unge er en del af virksomhedens image: hurtige, lærevillige og omstillingsparate

- Virksomheder ser ikke de ældres resurser: stabile, serviceorienterede, ansvarlige og flexible

Ethvert fagforbund og større bedrift med respekt for sig selv har en seniorpolitik. Alligevel er kun de færreste i midt-60erne på arbejdsmarkedet, selv om tallet er stigende. De, som er på arbejdsmarkedet, er der, fordi de har indflydelse og frihed i arbejdet, et stærkt helbred og et godt arbejdsmiljø. Der er mange gode kræfter - især økonomiske - samlet om at fastholde de ældre på arbejdsmarkedet. Spørgsmålet er, om det er, hvad de ældre generelt ønsker? Ældre er jo forskellige. Nogle ønsker givetvis at forlade arbejdsmarkedet så snart som muligt; andre kunne godt tænke sig at blive ved, til de segner. Men det grå guld er en realitet - statistisk set. Det er i øvrigt vanskeligt at blive enige om en definition: hvem er de ældre? Og hvor gamle er de ældre? 50 år? 60 år? 70 år? Er den kronologiske alder en vigtig faktor i forhold til arbejdslivet, eller er den irrelevant? The answer is blowing in the wind.

\section{Karriereudvikling}

Hvordan er vejlederne rustet til at tage fat på gerontovejledning, vejledning i forhold til de ældre, hvem de nu end er? Ikke ret godt: dette felt ligger endnu uden for de fleste karrierevejlederes synsfelt. Selv den omfattende norske NOU-udredning (NOU, 2016, s.7) traf ikke rigtigt på de ældre i sin 'helheltlige' tilgang til vejledning. For rigtig megen vejledning fokuserer på de unge - af gode grunde. Der er frafald og den slags. Og vi har jo ungdoms- og voksenvejledning. Men vejledning for ældre? Nja, ikke rigtigt. Nogle få projekter (Third Age Guidance: et EU/LdV projekt) og publikationer har fokuseret på 3rd Age Guidance (Bergmo-Prvulovic, 2017; Clayton et al. 2007; Ford \& Clayton, 2007; Plant, 2000a; 2000b; 2003). Og CEDEFOP har berørt emnet som en del af livslange lærings-temaer (CEDEFOP, 2012; 2015). Men der er langt imellem. Vejledere er ofte mere fokuserede på at vejlede ind i, op i og til noget, snarere end ud af, ned fra og sidelæns. Megen vejledning beskæftiger sig med, hvordan man kommer ind på uddannelser, ud på arbejdsmarkedet, frem til pensionen men sjældent med, hvordan man slipper derfra igen med livet/æren/pengene/ helbredet/ selvrespekten i behold. Det viser nylig forskning med eksempler fra det norske akademiske miljø, hvor det heller ikke er uproblematisk at blive gammel på jobbet. I interviews med kvindelige norske akademikere udtrykte de, at de - nu hvor de er blevet ca. 60 år og ældre - føler sig overset og ikke værdsat (Plant, Bakke \& Barham, 2019; Bakke, Barham \& Plant, 2020). Og de anser endda sig selv for at være nogle af de mere privilegerede på arbejdsmarkedet.

Fremtrædende og klassiske karriereudviklingsteorier på feltet hjælper heller ikke me- 
get. Super's model f.eks. (1957) indeholder følgende fem udviklingstrin, som antages at være generelle beskrivelser af en karriere, en livsbane:

- Vækst

- Undersøgelse

- Konsolidering

- Vedligehold

- Nedgang

Først op, så hen og så ned. Super kunne derfor gribe til regnbuen (the career rainbow) som en metafor for sin teori (Super, 1957). Nydeligt, velordnet - og middelklasse. Men denne type tankegang duer tydeligvis ikke i det (sen)moderne: her går bevægelserne i alle retninger på alle stadier i livet. Der er ikke nogen tydelig op/ned akse. Sommetider går karrieren til siden og sommetider op i røg. Det traditionelle billede af karrieren som en stige, hvor man arbejdede sig op trin for trin, er brudt sammen. Du kan få en skammel at stå på midlertidigt eller et skateboard at rulle på, hvis du er heldig.

Og så er karriere-regnbue metaforen desuden en lineær og ret individualistisk model. Den bagvedliggende forståelse er, at livet i den tredje alder går ned ad bakke, fysisk og mentalt. Men andre kulturer ser dette på andre måder. F.eks. skriver Arulmani \& Nag-Arulmani (2004) på baggrund af deres indiske kultur, at livet er en rejse i disse fire faser:

\section{* Brahmacharya Ashrama}

(forberedelse, læring)

* Grahastha Ashrama (familie, karriere)

* Vanaprastha Ashrama (samfundstjeneste, ikke for personlig vinding)

* Sanyasa Ashrama (spirituel tjeneste for menneskeheden).
Dette at tage udgangspunkt i en værdi-baseret og samfundsmæssig dimension tager fokus væk fra en vestlig orienteret og individualistisk tilgang - og repræsenterer et andet syn på alder, visdom og samfundsengagement.

\section{Livslang læring og livslang vejledning}

Et af tidens honnørord er livslang loering. Til det hører livslang vejledning. Men hvad fylder vejlederne i begrebet livslang vejledning? Hvor langt er det lærende liv? Er det interessant for en virksomhed at investere i uddannelse til en medarbejder på 62 år? Hvor langt rækker vejledning? Som forholdene er nu, er den ældre overladt til en hel række vejledere og især rådgivere, som hver har deres interesser. F.eks.

- A-kasse (om delpension, deltidsarbejde, men nok mest om efterløn)

- Eldresagen (den mest generelt orienterede organisation)

- Patientforeninger (for personer, der lider af en bestemt sygdom)

- Fortæl din livshistorie (oplysningsforbund, museumsforeninger)

- Økonomisk rådgivning (pensionskasser, banker)

- Begravelsesrådgivning ('Køb din kiste i god tid', beder bedemændene os om)

De emner, som formodes at interessere de ældre, er mangfoldige: ud over helbred, familie, rejser, byder f.eks. www.thirdage.com på skønhed \& livsstil, kærlighed \& sex samt på arbejdsmarkedssiden: karrieresucces og jobjagt - efter 50 år. Hu hej, hvor det går. Hopla: Den tredje alder er frihedens og mulighedernes tid. Eller hur?

Men hvor får man individuel, uhildet vejledning om f.eks. at skabe sig glidende overgange mellem arbejde, ikke-arbejde, frivilligt 
arbejde eller uddannelse? Nogle personale rekrutterings virksomheder tilbyder f.eks. tidligere ledere hjælp med at skaffe et seniorjob af en passende kaliber. Men for de fleste er der ikke meget hjælp at få, hvis det gælder om f.eks. at finde et andet job som 55-60årig. Noget dækkende billede af vejledning for ældre er det vanskeligt at få, selv om f.eks. Gerontologisk Institut (www.geroinst.dk) og Senior Consult (www.senior-consult.dk) har samlet en rigdom af informationer om og for ældre. I forhold til arbejdsmarkedet er mange ordninger og initiativer rettet mod virksomhederne, snarere end enkeltpersoner. Da vore engelske kolleger undersøgte sagen i UK, blev de overraskede over både rigdommen, bredden og især hullerne i uddannelses- og erhvervsvejledning for den tredje alder (Ford, 1997). Og i Danmark blev voksenvejledning - som potentielt kunne være stedet for vejledning af de ældre - de facto nedlagt da VEU-Centrene (Voksen- og efteruddannelses centre) i 2018 blev nedlagt og erstattet af digital vejledning til stor fortrydelse for professionen og de voksne/ældre (Wisler, 2018).

\section{Vejledning for alle?}

Samfundet vil noget med karrierevejledning: skabe bedre balance på arbejdsmarkedet, dæmme op for frafald på uddannelsesinsti- tutioner, inkludere de marginaliserede, integrere de fremmede, skabe et konkurrencedygtigt samfund, skabe en bæredygtig fremtid, m.m.. Alt dette skal vejledning understøtte, hjælpe til med eller ligefrem ordne. Uddannelsesvejlederen, studievejlederen, coachen, mentoren, erhvervsvejlederen er og var nogle af samfundets svar på den kollektive omsorg for og kontrol med næste generations problemer mht. at finde en uddannelse og et arbejde. Men samfundets bekymring, interesse og kontrol rækker langt ud over ungdomsgruppen. Det mærker f.eks. de arbejdsløse, som skal lægge en handlingsplan eller lægge deres CV på internettet - med hjælp fra en vejleder. Og nu er turen kommet til de ældre - for de ses som en resurse, et langt skridt fra 'ældrebyrden'. Men hvor går de hen med deres vejledningsbehov? For tiden til interesseorganisationer, som har et særligt perspektiv på denne brede og differentierede vejledningsopgave. Men en egentlig voksenvejledning, endsige ældrevejledning, det findes ikke. Endnu. Set i lyset af den aktuelle politiske fokus på tidlig tilbagetrækning fra arbejdsmarkedet for nogle grupper - udmøntet i kampagnen 'Nu er det Arnes tur' - kan der være et politisk vindue på klem for en egentlig ældrevejledning på neutral grund, gerne i brede partnerskaber, som omfatter arbejdsmarkedets parter, kommunale/regionale myndigheder og ældreorganisationer.

\section{ReferenCer}

Arulmani, Gideon \& Sonali Nag-Arulmani (2004). Career Counselling. A handbook, New Delhi: Tata Mc Graw-Hill Publishing.

Bakke, I. M., Lyn Barham, \& Peter Plant (2020). As Time Goes By: Geronto Guidance. I E. Haug, T. Hooley, J. Kettunen \& R Thomsen (red), Career Guidance in the Nordic Countries. London: Routledge (in press).

Bergomo-Prvulovic, I. (2017). Demographic changes and the need for later career opportunities. Adult Education Discourses, 18, 187-206.

CEDEFOP (2012). Promoting lifelong learning for older workers. An international overview. Thessaloniki: CEDEFOP.

CEDEFOP (2015). Increasing the value of age. Guidance in employers' age management strategies. Thessaloniki: CEDEFOP. 
Clayton, P., Greco, S. \& Persson, M. (2007). Guidance for life. Working and learning in the Third Age. Milano: FrancoAngeli.

Ford, Geoff (1997). Career Guidance in the Third Age: A Mapping Exercise. Cambridge: CRAC.

Ford, Geoff \& Clayton, P. (2007). Improving Learning and Career Guidance for Older People. Good practice guide for career guidance practitioners, policymakers, social partners and employers. Glasgow: University of Glasgow.

NOU (2016). 7: Norge i omstilling - karriereveiledning for individ og samfunn. Oslo: Kunnskapsdepartementet, https://www.regjeringen.no/no/ dokumenter/nou-2016-7/id2485246/

Plant, P. (2000a). Geronto vejledning. RUE-REVUE, 3, 3-6.
Plant, P. (2000b). Mandsopdoekning. Evaluering af et forløb for senior ingeniører, Frederiksborg Amt, februar-august 2000. København: Danmarks Pædagogiske Universitet.

Plant, P. (2003). Det Saerlige Seniorforløb. Evaluering af et vejledningsforløb for seniorer. København: Personalestyrelsen og Centralorganisationernes Fællesudvalg

Plant, P. (2010). Uddannelses- og erhvervsvejledning. I Leksikon.org, https://www.leksikon.org/ art.php? $\mathrm{n}=5159$

Plant, P., Bakke, I. M. \& Barham, L. (2019). Geronto Guidance: Lifelong Guidance. NICEC Journal, 41, 3-9.

Super, D. E. (1957). The Psychology of Careers. New York: Harper \& Row.

Wisler, O. (2018). eVoksenvejledertoget kører - skinnerne lægges undervejs. Vejlederen, 4, 10-13.

Peter Plant, professor

University of South-East Norway

e-mail: peter@roejle.dk 